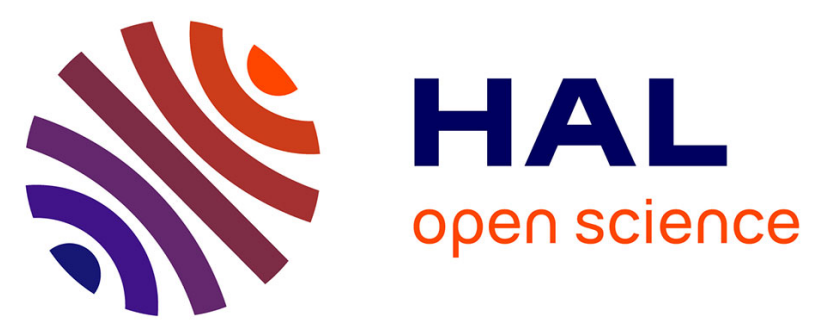

\title{
A product of social mission, sustainable entrepreneurial and marketing orientation: enhancing social entrepreneurial self-efficacy in Indonesian education sector
}

\author{
Satria Bangsawan, Muhammad Haseeb, Mahrinasari Ms
}

\section{To cite this version:}

Satria Bangsawan, Muhammad Haseeb, Mahrinasari Ms. A product of social mission, sustainable entrepreneurial and marketing orientation: enhancing social entrepreneurial self-efficacy in Indonesian education sector. Journal of Security and Sustainability Issues, 2020, 10 (October), pp.163 - 178. 10.9770/jssi.2020.10.oct(12) . hal-03121047

\section{HAL Id: hal-03121047 \\ https://hal.science/hal-03121047}

Submitted on 26 Jan 2021

HAL is a multi-disciplinary open access archive for the deposit and dissemination of scientific research documents, whether they are published or not. The documents may come from teaching and research institutions in France or abroad, or from public or private research centers.
L'archive ouverte pluridisciplinaire HAL, est destinée au dépôt et à la diffusion de documents scientifiques de niveau recherche, publiés ou non, émanant des établissements d'enseignement et de recherche français ou étrangers, des laboratoires publics ou privés. 
JOURNAL OF SECURITY AND SUSTAINABILITY ISSUES

ISSN 2029-7017/ISSN 2029-7025 (online)

2020 Volume 10 Number (October)

http://doi.org/10.9770/jssi.2020.10.Oct(12)

Scopus

\title{
A PRODUCT OF SOCIAL MISSION, SUSTAINABLE ENTREPRENEURIAL AND MARKETING ORIENTATION: ENHANCING SOCIAL ENTREPRENEURIAL SELF-EFFICACY IN INDONESIAN EDUCATION SECTOR
}

\author{
Satria Bangsawan ${ }^{1}$, Muhammad Haseeb $^{2 *}$, Mahrinasari MS ${ }^{3}$ \\ ${ }^{1,3}$ Faculty of Economics and Business, The University of Lampung, Indonesia \\ ${ }^{3}$ Taylors Business School (TBS), Taylors University Malaysia \\ E-mails: ${ }^{1}$ satria.bangsawan61@gmail.com; ${ }^{2 *}$ muhammad.haseeb@taylors.edu.my (Corresponding Author) \\ 3pr1nch1t4@yahoo.com;
}

Received 15 January 2020; accepted 10 July 2020; published 30 October 2020

\begin{abstract}
In the current era, there is a major need to make some effective development in the social entrepreneurship based strategic approach in business development. This paper is an informative approach based on critically consider the number of external factors that enhanced the self-efficacy of social entrepreneurship in the education sector of Indonesia. In this paper, social mission orientation, sustainability entrepreneurial orientation, and marketing orientation are act as an independent variable, risk management as a moderator, while social entrepreneurial self-efficacy is studied as a dependent variable. An online survey-based quantitative research method is used for data collection. After implementing the structural equation modeling (SEM) and moderation analysis based statistical testing, it becomes concluded that risk management acts as a strong moderator which enhance the influence of sustainability entrepreneurial orientation and marketing orientation on the social entrepreneurial self-efficacy. But the social mission orientation does not majorly impact on self-efficacy because of its higher risk factor. This is an attractive approach in front of the Indonesian education sector to enhance their understanding regarding the efficient social entrepreneurship that helps them to make a long-lasting decision. No doubt, this is a challenging and informative paper but there are some limitations like lack of mixed method based versatile research and lack of value cocreation factor may impact the authenticity of this paper which can be overcome by the upcoming related field scholars.
\end{abstract}

Keywords: Social Mission; Sustainable Entrepreneurial and Marketing Orientation

Reference to this paper should be made as follows: Bangsawn, S., Haseeb, M., Ms, M.. 2020. A Product of Social Mission, Sustainable Entrepreneurial and Marketing Orientation: Enhancing Social Entrepreneurial Self-Efficacy In Indonesian Education Sector. Journal of Security and Sustainability Issues, 10(Oct), 163-178. http://doi.org/10.9770/jssi.2020.10.Oct(12)

JEL Codes: O20, O31

\section{Introduction}

In 1994, a curriculum was prescribed to help the education sector of Indonesia to act confidentially and confidently in curricular decision making to enhance its self-efficacy beliefs (Brown, 2018). New market entry opportunities can be determined with the help of entrepreneurial orientation (EO), and it also helps in maintaining the sustainability, culture, environment, and economy of an organization (Novianti \& Nurlaelawati, 2019; Wichitsathian, \& Nakruang, 2019). There are several higher learning institutes in Indonesia, and the Dutch people consider these institutes beneficial and advantageous instead of other learning institutions (Setiawan \& Saputri, 2019). 
According to Yulianti, Denessen, and Droop (2019), EO acts as a bridge between value co-creation and the performance of the market, and it has a positive impact on market orientation as well as self-efficacy. Sustainability symbolizes an innovative mission to conserve long-term firm survival and to generate social values. Social mission orientation in an organization helps in influencing the eagerness through an effectual, sustainability orientation (SO), and innovativeness (Parker, 2017). Risk management plays an important role in strengthening the relationships among pro-activeness and SO (Assegaf, 2017).

The given Table 1, listed top risks facing by the Indonesian education sector in the past few years

Table 1: Top risks facing by the education sector

\begin{tabular}{lrlll}
\hline $\mathbf{2 0 1 5}$ & $\mathbf{2 0 1 6}$ & $\mathbf{2 0 1 7}$ & $\mathbf{2 0 1 8}$ \\
\hline Student recruitment & $\begin{array}{l}\text { Investment in technologies, } \\
\text { cybersecurity and data } \\
\text { information }\end{array}$ & $\begin{array}{l}\text { Information technology and } \\
\text { systems }\end{array}$ & $\begin{array}{l}\text { Government rules as well as } \\
\text { the political landscape }\end{array}$ \\
\hline $\begin{array}{l}\text { Research funding } \\
\text { quality }\end{array}$ & and & $\begin{array}{l}\text { Student recruitment and } \\
\text { financial sustainability }\end{array}$ & Financial sustainability & $\begin{array}{l}\text { Information } \\
\text { cybersecurity }\end{array}$ \\
\hline $\begin{array}{l}\text { Government rules } \\
\text { landscape }\end{array}$ & and & $\begin{array}{l}\text { Transformational change } \\
\text { program and investment }\end{array}$ & $\begin{array}{l}\text { Transformation programs and } \\
\text { organizational change }\end{array}$ & $\begin{array}{l}\text { Reputations } \\
\text { sustainability }\end{array}$ \\
\hline
\end{tabular}

There is not only a lack of entrepreneurial sustainability, market orientation, and social mission in the education sector of Indonesia but also a lack of entrepreneurial abilities and self-efficacy in the workers of that sector (Saidek \& Islami, 2016). Self-efficacy and sustainability should be enhanced by increasing their capability and capacity because it will result in satisfying the employees from their jobs that will result in increasing the level of self-efficacy (Ma'arif, 2018). Manzo, Lestari, and Atirennu (2019) Also describe that the values and opportunities should be created to meet social needs and to increase social entrepreneurship. There is a lack of motivation among the employees of the education sector of Indonesia (Sulisworo, 2016).

Establish on the outcomes of previous efforts, it comes to the knowledge that significant efforts have been conducted in the previous year's regarding social entrepreneurial self-efficacy (SES) from different perspectives. An effort recently by Amri, Bird, Ronan, Haynes, and Towers (2017) has evaluated the role of SES and value cocreation to determine the crucial differences among sustainability entrepreneurial orientations SEO and additions to the market. So, this indicates that much of the efforts have been completed in the last few years concerning SES (Grabara, Hussain \& Szajt, 2020). Though, the research has not been conducted concerning the Indonesian education sector and its overall performance in terms of entrepreneurial orientation (EO). Moreover, none of the past researches has evaluated the significant role of marketing orientation in improving the existing performance in terms of SES. Hence, the results as well as findings of the given study prove to be very helpful for the education sector of Indonesia in understanding the behavior of SEO and marketing attitude on SES. Besides, a recent study by Elmira and Suryadarma (2020) has analyzed the impact of SEO in different conditions and perspectives. Consequently, the following effort is remarkable and justified certainly because no other study has evaluated the mediating impact of risk management in enhancing the association between SEO and SES. The major goals of the current article are given below:

- The fundamental objective of the study is to examine the relationship between social mission orientation and social entrepreneurial self-efficacy (SES) in the education sector of Indonesia.

- The second goal of the paper is to evaluate the association between sustainability entrepreneurial orientations (SEO) an social entrepreneurial self-efficacy (SES) in the education sector of Indonesia. 
JOURNAL OF SECURITY AND SUSTAINABILITY ISSUES

ISSN 2029-7017/ISSN 2029-7025 (online)

2020 Volume 10 Number (October)

http://doi.org/10.9770/jssi.2020.10.Oct(12)

- The next objective is to identify the direct impact of marketing orientation on the social entrepreneurial self-efficacy in the education sector of Indonesia.

- The fourth target is to determine the mediating impact of risk management (RM) on the linkage between social mission orientation and SES in the education sector of Indonesia.

- The fifth aim is to analyze the mediating impact of RM on the connection between sustainability entrepreneurial orientations (SEO) and social entrepreneurial self-efficacy (SES) in the education sector of Indonesia.

- The final objective of the paper is to identify the mediating role of risk management in the connection between marketing orientation and social entrepreneurial self-efficacy in the education sector of Indonesia.

The current study is very significant as it evaluates the worth and value of social mission orientation and its role in the sustainable entrepreneurial and marketing orientation in enhancing social entrepreneurial and a positive influence in improving self-efficacy. This study is very helpful for the managers, owners, and the market salesmen as it expresses the points and sources to maintain sustainability in the production sector and also a kind of information and knowledge about the market place to start work with complete awareness about the market and its demands. The scope of this study is very wide as it helps in keeping a balance in the education sector.

The structure of the given research is as follows; it starts with the introduction of the study which generally provides a brief statement of the origin of the issues and certain problems. The initial chapter of the study also states the significance of the findings along with the scope of the research. The chapter of the literature review or theoretical framework mainly deals with related concepts and statements. Furthermore, the chapter of the methodology includes the study design and procedures of data gathering from different education institutions. The section of data analysis summarizes the data gathering and presents its complete analysis it a table form. And, finally, the chapter of conclusion and discussion gives an overview of the study findings.

\section{Literature review}

\subsection{Theory of social entrepreneurial orientation (SEO)}

According to Liu and Huang (2020), social entrepreneurship is a practice by groups and individuals, start-up firms, and entrepreneurs in which they majorly generate, fund as well as execute solutions to social and ecological problems. According to the theory of SEO, social entrepreneurship in different sectors offers an altruistic way of entrepreneurship that mainly empower entrepreneurs so that they can focus on the advantages that sectors and societies may reap (Martínez-Climent, Rodríguez-García, \& Zeng, 2019). According to this theory, social entrepreneurs of education sectors recognize immediate social issues and challenges and also keen to understand the significant context of problems that crosses some rules, policies as well as discipline (Turpin \& Shier, 2020). Besides gaining a huge understanding of how a problem concerns to society allows social entrepreneurs to generate some innovative as well as effective solutions and empower available resources to affect a significant scale of society and this all develop majorly due to effective risk management (Alarifi, Robson, and Kromidha (2019). Moreover, Parveen, Jaafar, and Ainin (2016) in research analyzed that from the basic corporate type of business, these types of entrepreneurial orientation (EO) ventures focus on increasing social gains as well as social entrepreneurship self-efficacy, rather than increasing financial benefits (Hussain et al., 2020).

\subsection{The relationship between social mission orientation (SMO) and social entrepreneurial self-efficacy (SES)}

A mission is an important task that people individually or a group of people perform to achieve the desired goal (Liu \& Huang, 2020). social mission orientation generally deals with a specific environment to obtain the goals. 
JOURNAL OF SECURITY AND SUSTAINABILITY ISSUES

ISSN 2029-7017/ISSN 2029-7025 (online)

2020 Volume 10 Number (October)

http://doi.org/10.9770/jssi.2020.10.Oct(12)

Social mission orientation SMO deals with creating an environment to work with collaboration and generating a friendly environment (Studdard et al., 2017; Iqbal, Z., et al., 2020). According to Brändle, Berger, Golla, and Kuckertz (2018) social mission focus on developing such an environment in which every individual is involved in playing a positive role and collaboration to perform their duties. The social mission involves all the employees, managers, management, supply chain system, employees, and all those shareholders and stakeholders as well (Ip, $\mathrm{Wu}$, Liu, \& Liang, 2017). Under such SMO there is a positive establishment of social entrepreneurship through the means of self-efficacy (Aziz, Abdul Rahim, \& Bukhari, 2017; Sajid, S., 2020). Self-efficacy is selfdetermination or the qualities to tackle all the issues and manage all the aspects leading the team of the workforce to achieve all the goals. There is a perfect and very positive influence of the social mission orientation SMO and also the social entrepreneurial self-efficacy SES. Self efficacy makes everyone believe in his own abilities and duties in order to perform best. Thus every member of the firm or the organization plays a vital and very significant role to lead his firm far beyond the progress and development (Gerleve \& Flatten, 2019). Therefore, the given study recommends the following hypotheses,

H1: There is a consequential relationship among social mission orientation and social entrepreneurial selfefficacy.

\subsection{The association between sustainability entrepreneurial orientation (SEO) and SES}

Sustainability entrepreneurial orientation is a term that deals with the ability to know and managing the matters regarding business and also the ability to make decisions and accept the challenges to face the competitors. The companies or the organizations evaluate the skills and the deficiencies to make plans to achieve sustainability and also a strong workforce to achieve the desired goals(McGee \& Peterson, 2019). To maintain sustainability, business management makes such policies and strategies that may help them to stable their position and they can lead to success and achievement. In making possible such policies and strategies there must be a relationship between SES. Besides, self-efficacy is a feeling of thinking innovations, positivity, creation, and also the ability to deal with the challenges of the modern age (Mei et al., 2017). Social entrepreneurial self-efficacy leads every individual towards success and achievement and a positive response when every individual is acknowledged and their efforts are appreciated with a positive ideology to make every possible effort to do best for the betterment of the company. Hence, the entire discussion leads to the below hypotheses,

H2: There is a positive relationship between sustainability entrepreneurial orientation and SES.

\subsection{The relationship between marketing orientation (MO) and SES}

The marketing orientation is an entrepreneurial as well as a business approach where the focus of entrepreneurs is on determining individuals' requirements, wants, and meeting them (Newman, Obschonka, Schwarz, Cohen, \& Nielsen, 2019). Different previous studies such as (Studdard et al., 2017) manifest that when a sector has a MO approach, it mainly focuses on developing and delivering services that satisfy customer requirements to be social entrepreneurial and to be profitable through SES. Successful marketing-oriented sectors discover and meet the fundamental desires of its customers through its high self-efficacy entrepreneurs. MO is a customer-centered process to service design that majorly involves identifying what customers or clients view as their quick needs and personal preferences within a certain service category (Shahab, Chengang, Arbizu, \& Haider, 2019). On the other hand, self-efficacy is an ability which generally mirrors an entrepreneur's beliefs in his capabilities to finish a social task, and solve issues or complete a certain set of tasks. SES was suggested as a new idea and variable to evaluate entrepreneurs' behavior towards social tasks such as MO that influence customers' perceptions, efforts, beliefs, and levels of input (Kumar \& Shukla, 2019; Kong \& Zhao, 2020). In short, owing positive self-efficacy benefits education sector entrepreneurs accept the social environment and persist in their jobs and develop an effective MO plan than those within-significant levels of self-efficacy. SES viewed as a significant and supportive variable to check the marketing performance of entrepreneurs, has some processes that develop further generation and significant application. Such as, self-efficacy is viewed to be a major evocator of entrepreneurs' self- 


\section{JOURNAL OF SECURITY AND SUSTAINABILITY ISSUES}

ISSN 2029-7017/ISSN 2029-7025 (online)

2020 Volume 10 Number (October)

http://doi.org/10.9770/jssi.2020.10.Oct(12)

confidence in experiencing challenges that advantages education experts successfully provide services in the altering education market. In short, the below hypotheses were suggested by the study,

H3: There is a significant relationship between marketing orientation and social entrepreneurial self-efficacy.

\subsection{The mediating role of risk management in the relationship between SMO and SES}

Risk management plays a vital role in SES in the education sector because self-efficacy can be attained by the establishment of social, physical skills, and complex cognitive and of an individual through different experiments and experiences. According to (Darmanto \& Yuliari, 2018; Li, \& Xu, 2020), the self-efficacy of an individual can be developed with the help of self-perception of his abilities and skills, and it results in achieving the goal efficiently. Perceptions and risk decision-making play a mediating role in the relation of SES and SMO by motivating the entrepreneurs to influence risk management. The outcomes of the risk management depend on the environment of the organization, either it will be positive or negative. Risk responses help to determine the results of risk management in an organization, and the influencing factors are more focused instead of the internal mechanism of an organization (Khalid, Bashir, \& Saqib, 2018). The entrepreneurs are encouraged to share their ideas that are concerned with creating new social values, planning to fulfill the tasks and goals, and addressing how to let these ideas meet the social needs if a social mission is adopted in an organization (Gómez-Fernández \& Albert, 2020). Hence, the current research proposes the following hypotheses,

H4: Risk management plays a significant mediating role in improving the association between SMO and SES.

\subsection{The mediating impact of risk management in the connection between SEO and SES}

Opposed to EO, risk management (RM) according to Liu and Huang (2020) is the mechanism of identifying, evaluating, and managing threats and risks to an institutional capital as well as finances. Besides, these risks and threats could come from a category of sources such as financial uncertainty, strategic management inaccuracies, and some type of legal liabilities. According to Zeb, ASajid, and Iqbal (2019), IT security risks, and other dataregarding threats and the threat management approaches to alleviate them, have become a major priority for digital entrepreneurs. Appropriately, a risk management process significantly includes institutions processes for identifying and managing education-related risks to its digital assets such as proprietary data and intellectual property (IP). Moreover, by executing a successful RM plan and addressing the several potential threats and the education sector can improve the sustainability level of EO and in this way, the self-efficacy of their entrepreneurs becomes significantly high. This is mainly because a significant RM plan will help an education institution develop procedures as well as mechanisms to avoid potential data risks, reduce their impacts should they happen, and fight with the outcomes. Therefore, the above discussion leads to the development of the following hypotheses,

H5: Risk management positively mediates the association between SEO and SES.

\subsection{The mediating role of risk management in the relationship between MO and SES}

Risk management in any organization has a very significant role to maintain the emergencies or issues regarding production and the supply chain and also deals with the external as well as internal matters (Raoof, Qureshi, \& Jabeen, 2019). Risk management overviews all the aspects that play a very positive and effective role in managing all affairs to make the possibility of a continuous process of the flow of business and also skills and abilities to deal with the rivals in every field .risk management plays a mediating role in developing a very strong bond with the marketing orientation and social entrepreneurial self-efficacy (Ahmed, Islam, \& Usman, 2020). marketing orientation makes the management able to make such policies and ideas that suit the organization .risk management team makes it possible for the organization to produce what suits and best for the market demand and socially acknowledged and accepted with a self-efficacy to deal with an unexpected situation or crisis and also to develop the production and the involvement of every individual to make the organization more established with a lot of innovations and energetic workforce.

H6: Risk management positively mediates the association between marketing orientation and SES. 
Research model is presented in Figure 1.

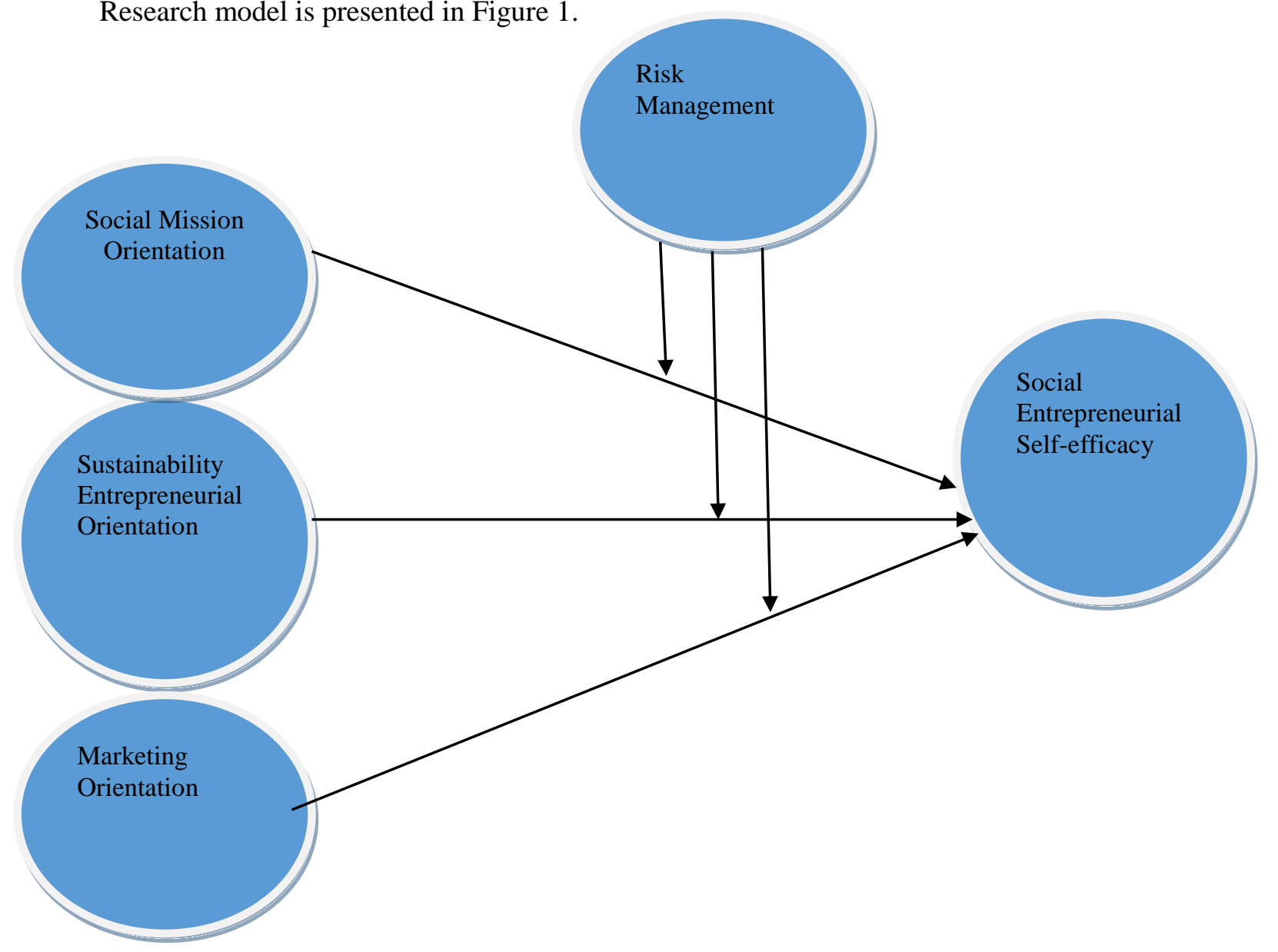

Figure 1: Research Model

\section{Methodology}

\subsection{Data Collection}

To inspect the influence of social mission orientation, sustainability entrepreneurial orientation, and marketing orientation on the social entrepreneurial self-efficacy, a quantitative research based informative method is used. In order to collect the relevant data, random online surveys were distributed among the related educational field participants in Indonesia. As, the major aim of this paper is to enhance the self-efficacy based social entrepreneurial activities within the educational field of Indonesia, so majorly its administration department, owners, infield working managers, and investors are considered to collect the opinion regarding this research hypothesis. So, a five-point Likert scale was used in the questionnaire based data collection process(Wu \& Leung, 2017), where social mission orientation, sustainability entrepreneurial orientation, and marketing orientation are considered as independent variables, social entrepreneurship self-efficacy act as a major dependent variable, while risk management act as a moderator within their relationship. 
JOURNAL OF SECURITY AND SUSTAINABILITY ISSUES

ISSN 2029-7017/ISSN 2029-7025 (online)

2020 Volume 10 Number (October)

http://doi.org/10.9770/jssi.2020.10.Oct(12)

\subsection{Sampling}

Firstly, the confirmation from the educational field professionals and scholars was collected before the random distribution of online survey. After this, 400 close-ended questions oriented questionnaires distributed among the educational field professionals on which approximately 386 were those who gave valid responses towards the asked questions. This 386 valid response based sample data is then categorized on the base of gender, age and experience. Like according to its descriptive statistics, 214 participants are males (55\% of total percentage) and the remaining 172 are females with $45 \%$. According to this outcome, it becomes clear that the percentage of actively participated males is 10 times more than females. After this, the age-based demographic segregation depicts that $32 \%$ of the overall selected Indonesian participants are less than 25 years old, $40 \%$ of them are within the age limit of 25 to 35 years old, $24 \%$ are from 35 to 45 years, while only $4 \%$ having more than 45 years old age. In case of their educational field based division, it becomes clear that only $14 \%$ of total having less than 2 years' experience, while $43 \%$ having 2 to 5 years based in-field management experience and $34 \%$ have 5 to 8 years based experience level, and only $10 \%$ of them are more than 8 years' experience in the educational field experience in the Indonesian market. All the above-selected sample based participants' evaluation depicts that maximum of the tested respondent is young, energetic, high potential, and new ideas containing individuals who having full information regarding this industry and all its consequences.

\subsection{Measurement}

In order to measure the authenticity and accuracy of this research, the original scales were selected from the wellknown educational journals. The descriptive statistics and factor loading based statistical tests will be implemented that helps either to justify or nullify the hypothesis, as shown in the following heading (Ringle, Sarstedt, Mitchell, \& Gudergan, 2018; Sardeshmukh \& Vandenberg, 2017). Also, the structural equation modeling (SEM) and moderation analysis based informative outcomes will be generated that helps to justify the relationship among the tested variables (Hayes, 2017; Ramayah, Cheah, Chuah, Ting, \& Memon, 2018).

\section{Analysis Interpretation}

Moderation analysis is a behavioral science that involves the use of linear multiple regression analysis or the causal modeling that easily quantify the impact of risk management based moderating variable in the multiple regression analyses. Also, structural equation modeling is an effective technique to study the relationship among the tested independent and dependent variables. The descriptive statistics of the related SPSS test discussed in the following Table 2 .

Table 2: Descriptive Statistics

\begin{tabular}{llllllll}
\hline & $\mathrm{N}$ & Minimum & Maximum & Mean & Std. Deviation & Skewness \\
\cline { 2 - 8 } & Statistic & Statistic & Statistic & Statistic & Statistic & Statistic & Std. Error \\
\hline RiskMang & 386 & 1.00 & 5.00 & 3.2934 & 1.02036 & -.214 & .124 \\
SESelfEff & 386 & 1.00 & 5.00 & 3.3426 & .96749 & -.385 & .124 \\
MarkOri & 386 & 1.00 & 5.00 & 3.5719 & 1.14494 & -.610 & .124 \\
SuEOri & 386 & 1.00 & 5.00 & 3.2055 & 1.19030 & -.284 & .124 \\
SpMOri & 386 & 1.00 & 5.00 & 3.3826 & 1.12001 & -.491 & .124 \\
Valid N (listwise) & 386 & & & & & & \\
\hline
\end{tabular}

According to the above-mentioned statistics, it becomes clear that the value of social entrepreneurial self-efficacy is less deviated from its mean position as compared to the other once, it means there are some external variables whose influence reduces the impact of the risk management factor in the relationship. Well, the sustainability entrepreneurial orientation highly deviates from its mean position which shows that this variable has little 
influence on the development of self-efficacy based strategic approach. Its KMO and Bartell's test based descriptions are shown in the following Table 3.

Table 3: KMO and Bartlett's Test

\begin{tabular}{|c|c|c|}
\hline Kaiser-Meyer-Olkin Measu & & .938 \\
\hline Bartlett's Test of Sphericity & Approx. Chi-Square & 7968.661 \\
\hline & Df & 171 \\
\hline & Sig. & .000 \\
\hline
\end{tabular}

According to the above statistics, the KMO value is 0.938 means within the threshold range. Also, its significance value is 0.00 lower than 0.05 with the appropriate chi-square value, which means this model is a good fit for the critical evaluation of variables. Well, the rotated component matrix-based statistical outcomes are discussed below in Table 4.

Table 4: Rotated Component Matrixa

\begin{tabular}{lllll}
\hline & Component & & & \\
& 1 & 2 & 3 & 5 \\
\hline RM1 & & .822 & & \\
RM2 & & .873 & & \\
RM3 & & .835 & & \\
RM4 & & .805 & .831 & \\
SE1 & & & .765 & \\
SE2 & & & .795 & \\
SE3 & & & .825 & \\
SE4 & & & & \\
MO1 & .918 & & & \\
MO2 & .866 & & & \\
MO3 & .837 & & & \\
MO4 & .887 & & & \\
MO5 & .915 & & & \\
MO6 & .896 & & & \\
MO7 & .879 & & & \\
EO1 & & & & \\
EO2 & & & & \\
SO1 & & & & \\
SO2 & & & & \\
\hline
\end{tabular}

The above matrix-based statistics depict that all of their rotated component values are more than 0.7 means all the variables are effectively uploaded in the tested mechanism. According to the following convergent and discriminant validity values, it becomes clear that there is no major issue faced in loading all the tested items (see Table 5). 
JOURNAL OF SECURITY AND SUSTAINABILITY ISSUES

ISSN 2029-7017/ISSN 2029-7025 (online)

2020 Volume 10 Number (October)

http://doi.org/10.9770/jssi.2020.10.Oct(12)

Table 5: Convergent and Discriminant Validity

\begin{tabular}{lllllllll}
\hline & CR & AVE & MSV & EO & RM & SE & MO & SO \\
\hline EO & 0.869 & 0.769 & 0.465 & $\mathbf{0 . 8 7 7}$ & & & & \\
RM & 0.916 & 0.731 & 0.319 & 0.377 & $\mathbf{0 . 8 5 5}$ & & & \\
SE & 0.895 & 0.682 & 0.340 & 0.405 & 0.565 & $\mathbf{0 . 8 2 6}$ & & \\
MO & 0.910 & 0.875 & 0.341 & 0.521 & 0.503 & 0.511 & $\mathbf{0 . 9 3 6}$ & \\
SO & 0.879 & 0.784 & 0.465 & 0.682 & 0.490 & 0.583 & 0.584 & $\mathbf{0 . 8 8 5}$ \\
\hline
\end{tabular}

Like, all the average variance extracted values of each tested item are more than 0.5 , while the composite reliability values are more than 0.7. Also, all the bold letters-based variables identification expose the major difference between the tested variables. After these values critical interpretation, it becomes concluded that there is no convergent and discriminant validity issue occurred within this testing model (see Table 6).

Table 6: Model Fit Indices

\begin{tabular}{llllll}
\hline CFA Indicators & CMIN/DF & GFI & IFI & CFI & RMSEA \\
\hline Threshold Value & $\leq 3$ & $\geq 0.80$ & $\geq 0.90$ & $\geq 0.90$ & $\leq 0.08$ \\
Observed Value & 2.197 & 0.922 & 0.979 & 0.979 & 0.056 \\
\hline
\end{tabular}

After this, the above confirmatory factor analysis based observed values show that all of them are within their related threshold range. For example, the observed value of CMIN/DF is 2.2 means lower than 3, also the GFI value is less than 0.80 (within the standard threshold range). While, the both IFI and CFI values are 0.979 (greater than 0.90), and also the RMSEA value is 0.056 which is lower than 0.08 , so it becomes concluded that this testing model is a good fit to implement the SEM based statistical analysis and all the variables are effectively uploaded on the tested model. Its graphical representation is shown in the following figure 2.

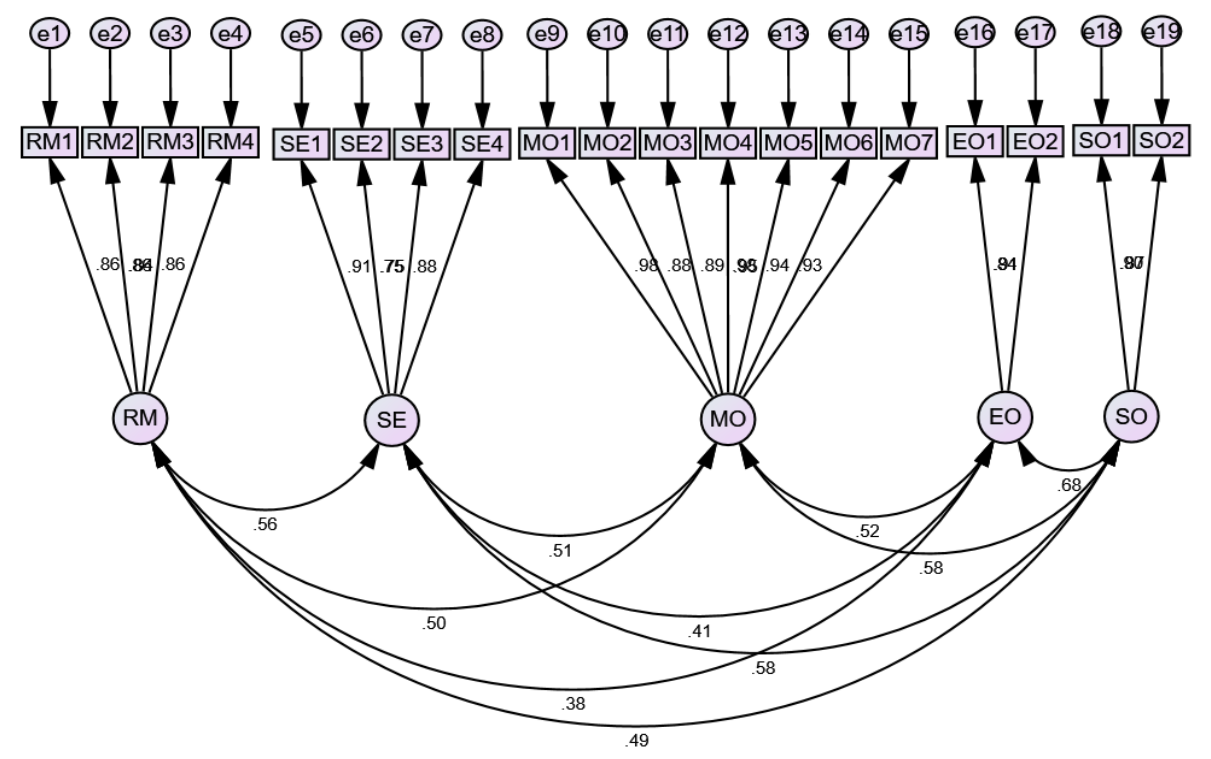

Figure 2: CFA 
After its CFA figure, the statistical information regarding the relationship between the tested independent, dependent and moderating variables are displayed in the following Table 7.

Table 7: Structural Equation Modeling

\begin{tabular}{lllllll}
\hline & Direct & & Estimate & S.E. & C.R. & P \\
\hline SESelfEff & $<---$ & SpMOri & .373 & .049 & 6.548 & $* * *$ \\
SESelfEff & $<---$ & SuEOri & -.017 & .045 & -.312 & .755 \\
SESelfEff & $<---$ & MarkOri & .283 & .043 & 5.521 & $* * *$ \\
& Moderation & & Estimate & S.E. & C.R. & P \\
ZSESelfEff & --- & RMSMO_Int3 & .067 & .039 & 1.574 & .115 \\
ZSESelfEff & --- & RMSEO_Int2 & .152 & .040 & 3.587 & $* * *$ \\
ZSESelfEff & $<---$ & RMMO_Int1 & -.096 & .038 & -2.256 & .024 \\
\hline
\end{tabular}

According to the above-mentioned statistics, it becomes clear that there is a direct influence of all the independent variables and moderator on the social entrepreneurial self-efficiency factor. Like, one percent change on the tested independent variable cause a positive impact on the development of an advanced education system. The above results depict that the outcome of social entrepreneurial self-efficiency is $49 \%$ change with the influence of social mission orientation, $45 \%$ due to sustainability entrepreneurial orientation, and $43 \%$ due to marketing orientation. Also, the risk management-based mediator boosts the relationship between both the major variables. According to the statistics, a combination of risk management with social mission orientation causes a $39 \%$ deviation in the self-efficacy factor, while its combination with sustainability entrepreneurial orientation results in $40 \%$, and with marketing orientation causes a 38\% deviation on the resultant value of social entrepreneurial self-efficacy. Its figure is given below in Figure 3.

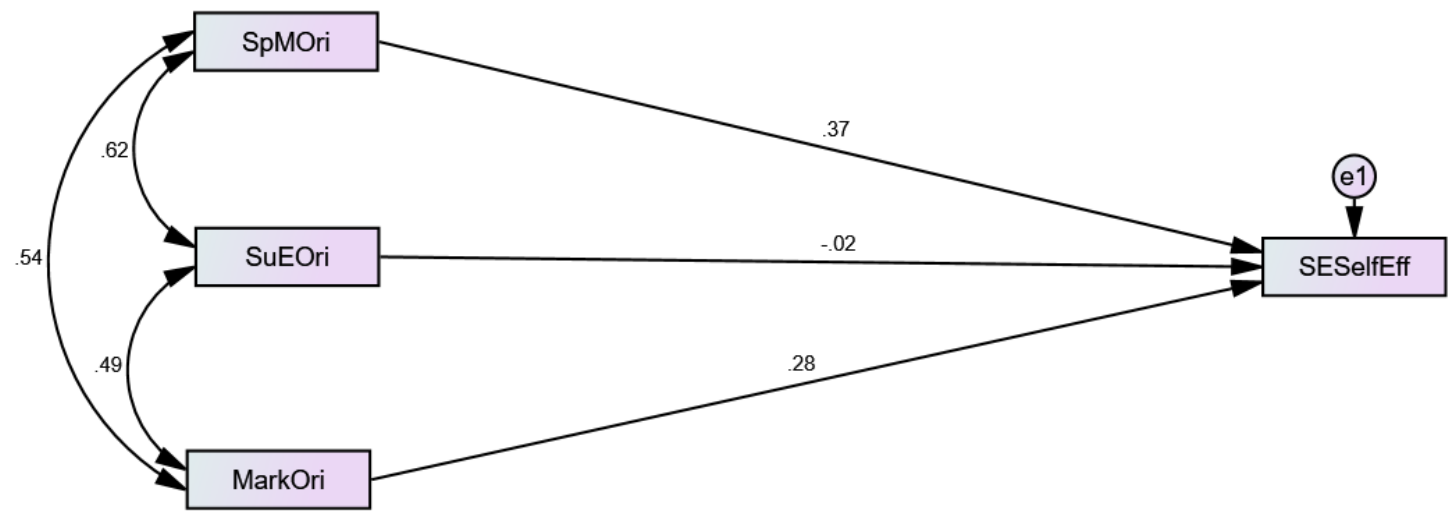

Figure 3: SEM

In order to make its moderation analysis, the following figure depicts that with the passage of time, the influence of risk management enhanced the influence of market orientation on the self-efficacy factor. But in the initial stage, its influence is not much affected the tested relationship. Its graphical representation is given below in Figure 4. 


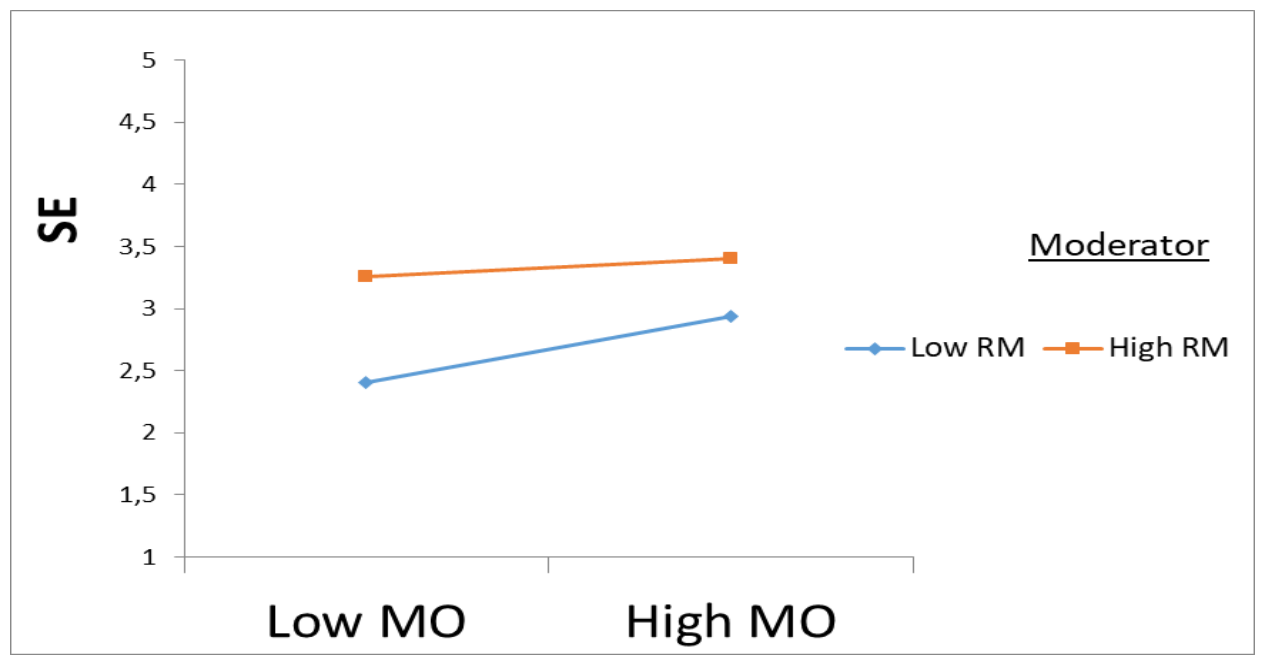

Figure 4: Moderation Role of Risk Management between Marketing Orientation and Social Entrepreneurial Self-Efficacy

After this in case of sustainability entrepreneurial orientation, the initial phase of risk management favorable impact on the desirable outcomes, but at the maximum point, its excess amount may create some threatening situation in front of management to stabilize their position in the diverse market. Its figure has been given below in Figure 5.

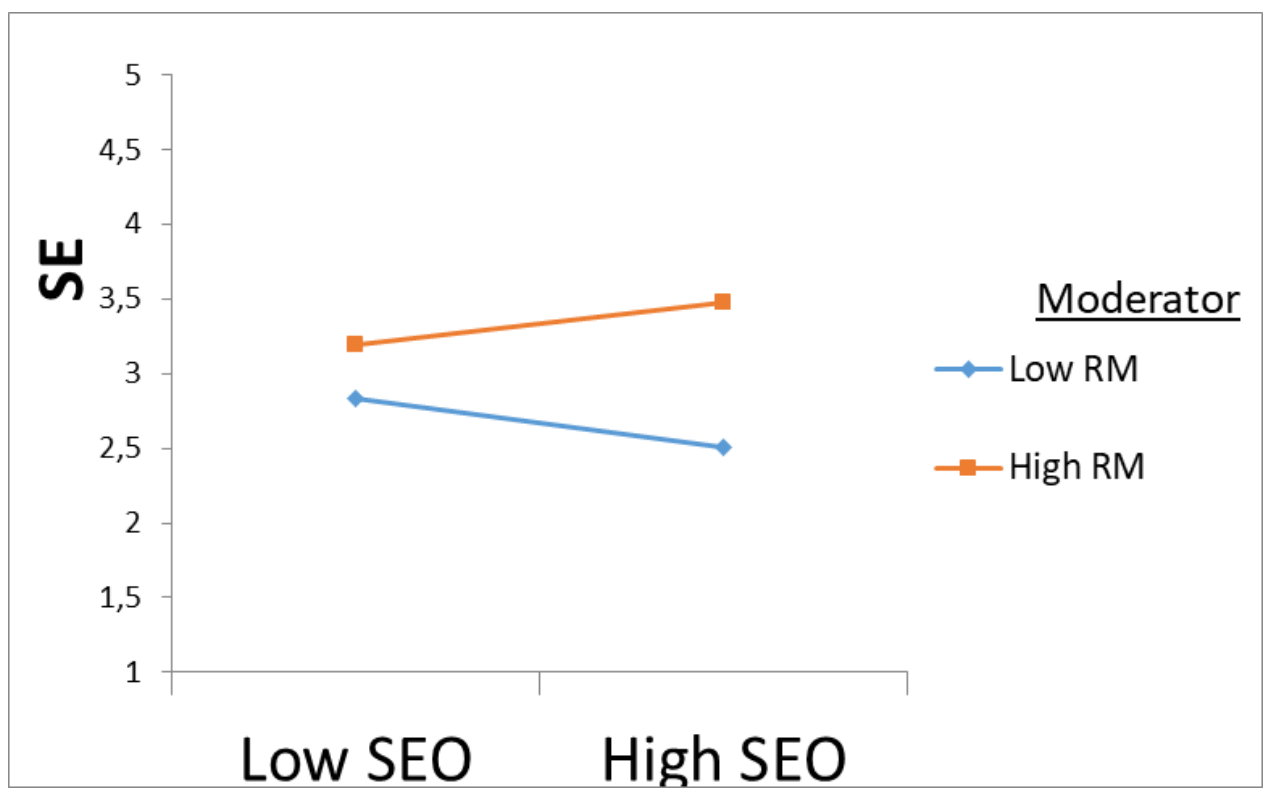

Figure 5: Moderation Role of Risk Management between Sustainability Entrepreneurial Orientation and Social Entrepreneurial SelfEfficacy

Last, but not the least, in case of social mission orientation; the moderator does not cause a major influence on this factor's impact on social entrepreneurial self-efficacy. So, this situation is uncontrollable in front of management to maintain their social mission. Its related graph is given below in Figure 6. 


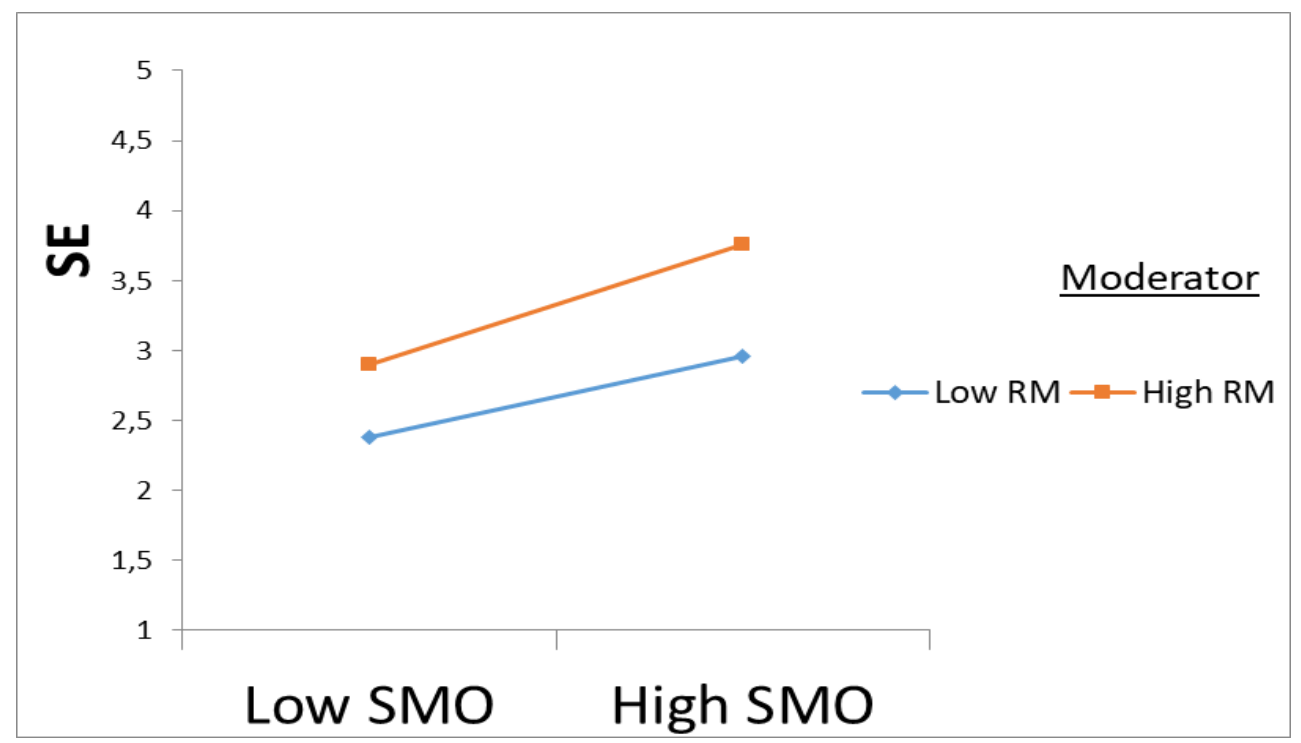

Figure 6: Moderation Role of Risk Management between Social Mission Orientation and Social Entrepreneurial Self-Efficacy

\section{Discussion and Conclusion}

After critically evaluate the statistical outcome, it becomes clear that marketing orientation and sustainability entrepreneurial orientation cause a major influence on the development of social entrepreneurial self-efficacy within the educational community in Indonesia. Chih-Hsing Sam Liu and Chiung-Eu Huang (2020) majorly designed a social entrepreneurial theory and studied a mediated-moderation model of the mutual relationship among the critical attributes of this theory by testing the buffering role of social entrepreneurial self-efficacy in the market and also the value co-creation processes. In their outcomes, they concluded that by utilizing the innovativeness, a social mission orientation directly influences the proactiveness, and also the risk management and effectual sustainability orientation strengthen the relationship between the proactiveness and sustainability orientation (Liu \& Huang, 2020). According to the above-mentioned analysis, it becomes clear that in the Indonesian educational industry, the risk management-based moderator effectively boosts the self-efficiency factor, but the social mission orientation is such a variable that does need this management role in its performance. In the previous researches, the researchers majorly worked on exploring the importance of social entrepreneurial antecedents on boosting the relationship between social entrepreneurial intent and prior experience in the education field. According to them, experience-based social issues within a developing state directly affect the moral obligation, empathy, perceived social support and social entrepreneurial self-efficacy. Because these are the actual motivation in front of a social entrepreneur to make some advanced changes in the traditional business activity (Barton, Schaefer, \& Canavati, 2018; Lacap, Mulyaningsih, \& Ramadani, 2018; M C., 2020). In the entrepreneurial intension, the personality traits, family factors, and self-efficacy play a major role in the development of an advanced entrepreneurial approach in the complex environmental situation. In addition to this, the extroversion, consciousness, and openness to experience enhanced the relationship (Farrukh, Khan, Khan, Ramzani, \& Soladoye, 2017). In addition to this, in the Asia Pacific Journal of Innovation and Entrepreneurship, Tran and Korflesch majorly worked on the conceptual model of social entrepreneurship intention on exploring the social cognitive career theory. According to these scholars, it's a new concept that may give a new direction to consider social entrepreneurship (Tran \& Von Korflesch, 2016). 
JOURNAL OF SECURITY AND SUSTAINABILITY ISSUES

ISSN 2029-7017/ISSN 2029-7025 (online)

2020 Volume 10 Number (October)

http://doi.org/10.9770/jssi.2020.10.Oct(12)

It becomes concluded from the above-mentioned data that the existence of knowledge management positively boosts the direct impact of marketing orientation and the sustainability entrepreneurial orientation on the social entrepreneurial self-efficacy within the educational department in Indonesia. This paper is informative based on valid statistical data of the selected participants. According to the SEM and moderating analysis based statistics, it becomes concluded that social mission orientation in the Indonesian market caused the least impact on the social entrepreneurship self-efficacy factor due to the influence of external factors.

\subsection{Future Implications}

This is informative research in front of the education field-oriented business community, the policymakers, and also the entrepreneurs to critically consider the importance of social entrepreneurship and its influential variables. This paper also has ethical and academic implications in the Indonesian market perspective. The upcoming scholars can utilize this data for the analysis based discussion portion.

\subsection{Limitations and Future Researches}

Also, there are some limitations of this paper-like lack of mixed research method for data collection and the deficiency of value co-creation factor in hypothesis building may impact the authenticity of this paper. There is an opportunity in front of future researchers to overcome this gap in their future articles.

\section{References}

Ahmed, I., Islam, T., \& Usman, A. (2020). Predicting entrepreneurial intentions through self-efficacy, family support, and regret. Journal of Entrepreneurship in Emerging Economies.

https://www.emerald.com/insight/content/doi/10.1108/JEEE-07-2019-0093/full/html

Alarifi, G., Robson, P., \& Kromidha, E. (2019). The manifestation of entrepreneurial orientation in the social entrepreneurship context. Journal of Social Entrepreneurship, 10(3), 307-327.

https://www.tandfonline.com/doi/full/10.1080/19420676.2018.1541015

Amri, A., Bird, D., Ronan, K., Haynes, K., \& Towers, B. (2017). Disaster risk reduction education in Indonesia: challenges and recommendations for scaling up.

https://opinvisindi.is/handle/20.500.11815/337

Assegaf, A. (2017). Curbing Corruption Through Tertiary Education In Indonesia And Japan. Acehnese Wars And Learning From 12years Of Peace In Aceh, 261.

Aziz, A., Abdul Rahim, N. F., \& Bukhari, S. M. (2017). Mediating effect of entrepreneurial self efficacy between social networks, environmental dynamism, and entrepreneurial self-leadership and new venture success. Asian Journal of Multidisciplinary Studies, 5(2), 126-130.

http://repo.uum.edu.my/21860/

Barton, M., Schaefer, R., \& Canavati, S. (2018). To be or not to be a social entrepreneur: Motivational drivers amongst American business students. Entrepreneurial Business and Economics Review, 6(1), 9-35.

Brändle, L., Berger, E. S., Golla, S., \& Kuckertz, A. (2018). I am what I am-How nascent entrepreneurs' social identity affects their entrepreneurial self-efficacy. Journal of Business Venturing Insights, 9, 17-23.

https://www.sciencedirect.com/science/article/pii/S2352673417300835

Brown, W. E. (2018). Communicate Globally, Teach Locally: An Action Research Project Analyzing Self-Efficacy Competence of African American Native English Speakers (NESs) Teaching in a Foreign Placement. Northeastern University.

Darmanto, S., \& Yuliari, G. (2018). Mediating role of entrepreneurial self efficacy in developing entrepreneurial behavior of entrepreneur students. Academy of Entrepreneurship Journal.

Elmira, E., \& Suryadarma, D. (2020). Financing tertiary education in Indonesia: assessing the feasibility of an income-contingent loan system. Higher Education, 79(2), 361-375.

https://link.springer.com/article/10.1007/s10734-019-00414-3

Farrukh, M., Khan, A. A., Khan, M. S., Ramzani, S. R., \& Soladoye, B. S. A. (2017). Entrepreneurial intentions: the role of family factors, personality traits and self-efficacy. World Journal of Entrepreneurship, Management and Sustainable Development. 


\section{JOURNAL OF SECURITY AND SUSTAINABILITY ISSUES}

ISSN 2029-7017/ISSN 2029-7025 (online)

2020 Volume 10 Number (October)

http://doi.org/10.9770/jssi.2020.10.Oct(12)

Grabara, J., Hussain, H.I., Szajt, M. (2020) Sustainable University Development through Sustainable HR and Corporate Entrepreneurship: The role of Sustainable Innovation and Environment, Amfiteatru Economic, 22 (54), $480-495$. https://www.ceeol.com/search/article-detail?id=851882

Gerleve, C. V. H., \& Flatten, T. C. (2019). Developing Entrepreneurial Passion for Social Mission. Paper presented at the Academy of Management Proceedings.

https://journals.aom.org/doi/abs/10.5465/AMBPP.2019.37

Gómez-Fernández, N., \& Albert, J. F. (2020). ¿ Es la Eurozona un área óptima para suprimir el efectivo? Un análisis sobre la inclusión financiera y el uso de efectivo. Cuadernos De Economía, 43(121). https://doi.org/10.32826/cude.v43i121.107

https://link.springer.com/article/10.1186/s40497-018-0112-8

Hayes, A. F. (2017). Introduction to mediation, moderation, and conditional process analysis: A regression-based approach: Guilford publications.

https://www.jstor.org/stable/24018134?seq=1

Hussain, H.I., Kamarudin, F., Mohamad Anwar, N.A., Nassir, A.M., Sufian, F., Mang Tan, K. (2020), Impact of Country's Governance Dimensions on Bank Revenue Efficiency: Overview on Middle East, Southeast Asia, and South Asia Countries, Transformations in Business \& Economics, 19 (1), 191-228. http://www.transformations.knf.vu.lt/49/article/impa.

Ip, C. Y., Wu, S.-C., Liu, H.-C., \& Liang, C. (2017). Revisiting the antecedents of social entrepreneurial intentions in Hong Kong. International Journal of Educational Psychology, 6(3), 301-323.

Iqbal, Z., Adeel, M., \& Khan, M. M. (2020). The Effect Of Leadership Styles On Employees Job Satisfaction: A Case Study On Banking Sector Of Pakistan. Hamdard Islamicus, 43(3), 162-174.

Khalid, A., Bashir, M., \& Saqib, S. (2018). Collective Impact of Entrepreneurial Self-Efficacy and Risk Propensity on Entrepreneurial Intentions; Mediating Role of Perceived Social Support. International Journal of Engineering \& Technology, 7(3.21), 24-30.

Kong, F., \& Zhao, L. (2020). An investment portfolio for college students under the dependency and loss psychology of entrepreneurship. Revista Argentina de Clinica Psicologica, 29(1), 131-140. https://doi.org/10.24205/03276716.2020.17

Li, H., \& Xu, C. (2020). Visualizing the knowledge domain of psychological contract research through bibliometric analysis. Revista Argentina de Clinica Psicologica, 29(1), 268-278. https://doi.org/10.24205/03276716.2020.36

Kumar, R., \& Shukla, S. (2019). Creativity, Proactive Personality and Entrepreneurial Intentions: Examining the Mediating Role of Entrepreneurial Self-efficacy. Global Business Review, 0972150919844395.

Lacap, J. P. G., Mulyaningsih, H. D., \& Ramadani, V. (2018). The mediating effects of social entrepreneurial antecedents on the relationship between prior experience and social entrepreneurial intent. Journal of Science and Technology Policy Management.

Liu, C.-H. S., \& Huang, C.-E. (2020). Discovering differences in the relationship among social entrepreneurial orientation, extensions to market orientation and value co-creation-The moderating role of social entrepreneurial self-efficacy. Journal of Hospitality and Tourism Management, 42, 97-106.

Ma'arif, S. (2018). Education as a Foundation of Humanity: Learning from the Pedagogy of Pesantren in Indonesia. Journal of Social Studies Education Research, 9(2), 104-123.

https://bulenttarman.com/index.php/jsser/article/view/256

Manzo, A., Lestari, G. A., \& Atirennu, P. (2019). Education of Women and Citizenship in Indonesia from State Ibuism Perspective. THE Role Of Identity In Politics, 35.

Martínez-Climent, C., Rodríguez-García, M., \& Zeng, J. (2019). Ambidextrous leadership, social entrepreneurial orientation, and operational performance. Sustainability, $11(3), 890$.

https://www.mdpi.com/2071-1050/11/3/890

M C, Minimol. (2020). Women Entrepreneurship in Coastal Kerala: Role of Self Help Groups in Developing a Sustainable Community. Entrepreneurship and Sustainability Issues, 7(4), 3426-3437. http://doi.org/10.9770/jesi.2020.7.4(56)

McGee, J. E., \& Peterson, M. (2019). The long-term impact of entrepreneurial self-efficacy and entrepreneurial orientation on venture performance. Journal of Small Business Management, 57(3), 720-737.

Mei, H., Ma, Z., Jiao, S., Chen, X., Lv, X., \& Zhan, Z. (2017). The Sustainable Personality in Entrepreneurship: The Relationship between Big Six Personality, Entrepreneurial Self-Efficacy, and Entrepreneurial Intention in the Chinese Context. Sustainability, 9(9), 1649.

https://www.mdpi.com/2071-1050/9/9/1649

Newman, A., Obschonka, M., Schwarz, S., Cohen, M., \& Nielsen, I. (2019). Entrepreneurial self-efficacy: A systematic review of the literature on its theoretical foundations, measurement, antecedents, and outcomes, and an agenda for future research. Journal of Vocational Behavior, 110, 403-419.

https://www.sciencedirect.com/science/article/pii/S0001879118300587

Novianti, N., \& Nurlaelawati, I. (2019). Pedagogical Competence Development of University Teachers With Non-Education Background: The Case of A Large University of Education In Indonesia. International Journal of Education, 11(2), 169-177.

Parker, L. (2017). Religious environmental education? The new school curriculum in Indonesia. Environmental Education Research, 23(9), 1249-1272.

Parveen, F., Jaafar, N. I., \& Ainin, S. (2016). Social media's impact on organizational performance and entrepreneurial orientation in organizations. Management Decision. 
JOURNAL OF SECURITY AND SUSTAINABILITY ISSUES

ISSN 2029-7017/ISSN 2029-7025 (online)

2020 Volume 10 Number (October)

http://doi.org/10.9770/jssi.2020.10.Oct(12)

https://www.emerald.com/insight/content/doi/10.1108/MD-08-2015-0336/full/html

Ramayah, T., Cheah, J., Chuah, F., Ting, H., \& Memon, M. (2018). Partial least squares structural equation modeling (PLS-SEM) using SmartPLS 3.0 An Updated Guide and Practical Guide to Statistical Analysis: Pearson.

Raoof, R., Qureshi, I., \& Jabeen, S. (2019). Mediating Role of Entrepreneurial Self-efficacy in the relationship of Social Capital and Entrepreneurial Intentions. Dialogue (1819-6462), 14(2).

Ringle, C. M., Sarstedt, M., Mitchell, R., \& Gudergan, S. P. (2018). Partial least squares structural equation modeling in HRM research. The International Journal of Human Resource Management, 1-27.

https://papers.ssrn.com/sol3/papers.cfm?abstract_id=2233795

Saidek, A. R., \& Islami, R. (2016). Character Issues: Reality Character Problems and Solutions through Education in Indonesia. Journal of Education and Practice, 7(17), 158-165.

Sardeshmukh, S. R., \& Vandenberg, R. J. (2017). Integrating moderation and mediation: A structural equation modeling approach. Organizational Research Methods, 20(4), 721-745.

Sajid, S., Abdullah, N. B., \& Chik, A. R. (2020). Infrastructure Index And Female Labor Force Participation In Developing-8 Countries: A Demand Side Approach. Hamdard Islamicus, 43(2.), 243-262.

Setiawan, A. R., \& Saputri, W. E. (2019). STEAM Education: background, framework, and characteristics. EdArXiv. December, 27.

Shahab, Y., Chengang, Y., Arbizu, A. D., \& Haider, M. J. (2019). Entrepreneurial self-efficacy and intention: do entrepreneurial creativity and education matter? International Journal of Entrepreneurial Behavior \& Research.

Studdard, N., Dawson, M., Burton, S. L., Jackson, N., Leonard, B., Quisenberry, W., \& Rahim, E. (2017). Nurturing social entrepreneurship and building social entrepreneurial self-efficacy: Focusing on primary and secondary schooling to develop future social entrepreneurs Entrepreneurship: Concepts, Methodologies, Tools, and Applications (pp. 247-269): IGI Global.

https://www.igi-global.com/chapter/nurturing-social-entrepreneurship-and-building-social-entrepreneurial-self-efficacy/179665

Sulisworo, D. (2016). The Contribution of the education system quality to improve the nation's competitiveness of Indonesia. Journal of Education and Learning, 10(2), 127-138.

Tran, A. T., \& Von Korflesch, H. (2016). A conceptual model of social entrepreneurial intention based on the social cognitive career theory. Asia Pacific Journal of Innovation and Entrepreneurship.

https://www.emerald.com/insight/content/doi/10.1108/APJIE-12-2016-007/full/html

Turpin, A., \& Shier, M. L. (2020). Social Entrepreneurial Orientation in Human Service Organizations: A Scoping Review. Human Service Organizations: Management, Leadership \& Governance, 44(2), 144-168.

Wichitsathian, S., Nakruang, D. (2019). Knowledge integration capability and entrepreneurial orientation: case of Pakthongchai Silk Groups Residing. Entrepreneurship and Sustainability Issues, 7(2), 977-989. http://doi.org/10.9770/jesi.2019.7.2(13)

Wu, H., \& Leung, S.-O. (2017). Can Likert scales be treated as interval scales?-A Simulation study. Journal of Social Service Research, 43(4), 527-532.

Yalcin, I., \& Ramazanoglu, F. (2020). The Effect of Imagery Use on the Self-Confidence: Turkish Professional Football Players. Revista de Psicologia del Deporte, 29(2), 57-64

Yulianti, K., Denessen, E., \& Droop, W. (2019). Indonesian parents' involvement in their children's education: A study in elementary schools in urban and rural Java, Indonesia.

https://repository.ubn.ru.nl/handle/2066/204353

Zeb, N., ASajid, M., \& Iqbal, Z. (2019). Impact of individual factors on women entrepreneurial intentions: With mediating role of innovation and interactive effect of entrepreneurial self-efficacy. Journal of the Research Society of Pakistan, 56(2), 89. 
JOURNAL OF SECURITY AND SUSTAINABILITY ISSUES

ISSN 2029-7017/ISSN 2029-7025 (online)

2020 Volume 10 Number (October)

http://doi.org/10.9770/jssi.2020.10.Oct(12)

\section{Satria BANGSAWAN}

https://orcid.org/0000-0002-1264-5549

\section{Mahrinasari MS}

https://orcid.org/0000-0001-6333-6423

Hafiz Waqas KAMRAN

https://orcid.org/0000-0002-5220-457X

This work is licensed under the Creative Commons Attribution International License (CC BY).

http://creativecommons.org/licenses/by/4.0/

(c) (i) Open Access 